Lakócai Csaba ${ }^{1}$ :

\title{
A fejlődés és fejlettség sokfélesége a számok tükrében A GDP és néhány alternatív mutató értékének összevetése a világ országaiban
}

\author{
The diverseness of progress and development \\ A comparison of GDP and some alternative indicators among the countries of the world
}

A közgazdaságtani gondolkodásban az elmúlt fél évszázad során fokozatosan teret nyert az a nézet, miszerint újra kell gondolni a gazdaság feladatait és célját, feladva a termelékenység és fogyasztás vég nélküli növekedésébe vetett hitet. A kezdetben még csak néhány elméleti kutató körében terjedő meggyőződést a 2008-as pénzügyi válság óta már több politikai döntéshozó is magáénak vallja, jóllehet egyelöre szerkezeti korlátai (is) vannak a gazdaság másfajta, fenntarthatóbb pályára állításának. Egy, a közeljövőben esedékes strukturális változásban kulcsszerepet kap az, hogyan és mivel mérjük a makrogazdaság teljesítményét. Jelen tanulmányban a GDP, mint a legelterjedtebb makrogazdasági mutató kerül összevetésre néhány alternatív fejlettségi-jól(l)éti mutatóval statisztikai adatok alapján, rámutatva a fejlődés különböző megjelenési formáinak összetettségére, amit a jövőben a jelenlegi gyakorlathoz képest jobban figyelembe kell venni a fenntarthatóság érdekében.

Within the economic thinking, an opinion on the necessary reconsideration of the mission and objectives of the economy has gained ground over the past half century, giving up the belief in the infinite growth of productivity and consumption. Initially, this was only the conviction of a few theoretical scholars, but since the 2008 financial crisis, some decision makers agree with this thinking. However, there are still systemic limitations of switching the economy to a more sustainable path. In future structural transition, the question of how to measure the macroeconomic performance will be a key issue. In this paper, GDP, as the most broadly used economic index, is compared with some alternative welfare and wellbeing indices based on statistical data, underscoring the complexity and diversity of the different dimensions of progress and development. Decision makers should consider the latter fact more in the future than they do today.

\section{Bevezető: a téma aktualitása}

A legújabb, 2008-ban kezdődő gazdasági válságot követő években ismét előtérbe került az a nézet, miszerint újra kellene gondolni a makrogazdasági teljesítmény mérésére szolgáló GDP (gross domestic product, vagyis bruttó hazai össztermék) - vagy az egyes országokban ehelyett használt GNP (gross national product, vagyis bruttó nemzeti össztermék) - mutató célszerüségét a különböző gazdasági és/vagy társadalmi fejlesztéspolitikai prioritások és célkitüzések meghatározásakor. Ezt hangsúlyozza számos egyéb dokumentum mellett az Európai Bizottság 2009-es A GDP-n innen és túl-A haladás mérése változó világunkban címü közleménye, amelyet a Tanácsnak és az Európai Parlamentnek nyújtottak be, illetve a

\footnotetext{
${ }^{1}$ PhD hallgató, PTE KTK Regionális Politika és Gazdaságtan Doktori Iskola; tudományos segédmunkatárs, Közgazdaság- és Regionális Tudományi Kutatóközpont, Világgazdasági Intézet

DOI: 10.14267/RETP2021.01.03
} 
Régiók Bizottságának Területfejlesztési mutatók - a GDP-n innen és túl című 2016-os munkadokumentuma. Mindkét dokumentum a Stiglitz-Sen-Fitoussi vezette bizottság 2009-es jelentésének megállapításaiból és ajánlásaiból indul ki. Az alapfelvetés az, hogy amit mérünk, hatással van arra, amit teszünk, ezért a fenntarthatóság szempontjából elengedhetetlen (lenne) a politikai döntéshozóknak a GDP mellett egyéb szempontokat is jobban figyelembe venniük, akár alternatív mérőszámok és mutatók formájában [Jacobs-Šlaus, 2010].

Az az alapgondolat, miszerint a GDP - ami az egy adott területen (országban, régióban) egy adott időszakban (általában évben) termelt és felhasznált/elfogyasztott összes termék és szolgáltatás pénzben kifejezett értéke - nem alkalmas arra, hogy az emberi és társadalmi tevékenységek teljes spektrumát lefedje, illetve a gazdasági fejlődés egyetlen mutatója legyen, nem újdonság a hazai szakirodalomban sem. Kornai [1972] az egyetlen mutatóval történő mérés módszertani helytelenségére és káros következményeire hívja fel a figyelmet - ugyanabban az évben, amikor a Római Klub kiadta első jelentését $A$ növekedés határai címmel -, Bródy [1983] pedig annak veszélyére, hogy ennek rendeljenek alá minden egyéb szempontot. Ez a felismerés vezetett továbbá olyan alternatív, a GDP-t korrigáló mutatók megjelenéséhez, mint egyebek mellett az Egyesült Nemzetek Szervezete által publikált Emberi Fejlettségi Index (HDI) vagy a Daly és Cobb [1989] által kidolgozott Fenntartható Gazdasági Jóléti Mutató (ISEW). A Gazdasági Együttmüködési és Fejlesztési Szervezet is hasonló célból fejlesztette ki 2011-ben a Better Life nevü kompozit indexét, amely 11 dimenziót mér [Kerényi, 2011]. A szervezet honlapján keresztül lehetőség van arra, hogy az érdeklődő interaktív módon maga súlyozza ezeket a dimenziókat, ami természetesen a kompozit index eredményeinek és az országok közötti sorrendnek a megváltozásával jár mindig.

A 2009-es Stiglitz-jelentés abból a szempontból számít újnak, hogy a dokumentumot kimondottan politikai döntéshozók felkérésére készítették, és ennek megfelelően igyekszik konkrét közpolitikai intézkedések szintjére is átfordítható ajánlásokat tenni, bár az ebbéli sikere megkérdőjelezhető [Galambosné Tiszberger, 2016]. Egy, a GDP-t kiegészítő (vagy esetleg helyettesítő) aggregált mérőszámnak a jelentésben írtak szerint az alábbi területeket kell mérnie:

- anyagi jólét (jövedelem, fogyasztás és vagyon)

- egészségügy

- oktatás

- egyéni tevékenységek, beleértve a munkát

- politikai képviselet és kormányzat

- társadalmi kapcsolatok

- környezet állapota (jelenlegi és várható jövőbeli feltételek)

- gazdasági és fizikai bizonytalanság.

A londoni székhelyü New Economic Foundation jelentése [2015] - részben hasonlóképpen - öt területet nevez meg, amelyeket mérni kell az ország, ez esetben az Egyesült Királyság gazdasági teljesítményének értékeléséhez:

- érdemi munkahelyeket teremtő foglalkoztatáspolitika

- jóllét

- környezet

- méltányosság

- egészségügy

Számos egyéb hasonló koncepció létezik még a fentebb említetteken kívül, amelyek vagy kiegészítik, vagy korrigálják, vagy pedig teljesen lecserélik a GDP-t, és egyéb kompozit indexekkel helyettesítik azt [Grasso-Canova, 2007; Jacobs-Šlaus, 2010]. Jelen tanulmány ezek közül foglalkozik néhánnyal, összeveti 
azokat egymással. A vizsgált mutatók, valamint a kutatási kérdés és a módszertan bemutatását az eredmények ismertetése követi, majd ezek alapján általános következtetések megfogalmazásával zárul a tanulmány.

\section{Kutatási kérdések és vizsgált mutatók}

Jelen tanulmány alap kutatási kérdése az, hogy a fejlődés és a fejlettség fogalma milyen dimenziókkal fejezhető ki, és ezek milyen kapcsolatban állnak egymással, amennyiben elvetjük azt az egyoldalúan piacorientált szemléletmódot, miszerint csak a termelékenységi és fogyasztási adatokat aggregáló mutatókkal mérjük a fejlődést. Az ebből következő megközelítés cáfolja azt a nézetet, miszerint a GDPben mért minél nagyobb gazdasági növekedéssel lehetne csak megalapozni egy hatékony társadalom- és környezetpolitikát. Ezzel ellentétben a dolgozat alapfelvetése az, hogy a GDP mutatója még a fejlödésnek csak a gazdasági dimenzióját sem képes teljes egészében kifejezni, következésképpen a GDP-ben mért növekedés nem feltétlenül eredményezi a gazdaság állapotának javulását, sőt sok esetben e mutató értékének egy szint utáni további növelése már az egyéb (gazdasági) állapotváltozók (például megtakarítási ráta, szerkezeti kiegyensúlyozottság, ellenálló- és alkalmazkodóképesség stb.) romlását vonja maga után.

Az iménti állítások számszerü vizsgálatához olyan mutatókat kerestem, amelyek három dimenziónak, a gazdaságnak, a társadalomnak és a természeti környezetnek az állapotváltozóit aggregálják, és adataik a világ legtöbb országára rendelkezésre állnak a vizsgált időszakban. Elemzésemhez a 2016-os - vásárlóeröparitáson mért és amerikai dollárban kifejezett - egy före eső bruttó hazai össztermékértéket (GDP/fö) és négy alternatív kompozit mutatószámot vizsgáltam egy 150 országot tartalmazó alapsokaságban, szintén 2016-os adatokkal. A vizsgált 150 ország nagyjából lefedi a világ összes olyan országát, amelyekre minden mutató esetében rendelkezésre állnak a statisztikai adatok. A GDP-re vonatkozó adatok a Világbank honlapjáról származnak, az alternatív mutatók értékeit pedig további két adatállományból gyüjtöttem.

A hollandiai Sustainable Society Foundation (SSF) adatállományából származnak három aggergált jóléti mutatószámnak, az emberi jólétnek (HW - Human Wellbeing), a környezeti jólétnek (EnW Environmental Wellbeing) és a gazdasági jólétnek (EcW - Economic Wellbeing) az értékei. ${ }^{2}$ Ezek egy 1-től 10-ig terjedő skálán jelennek meg. Az 1. táblázat mutatja a három mutató összetételét. A pillérváltozók közül az élelmiszerre, ivóvízre, higiéniai körülményekre, oktatásra, egészséges életmódra, nemek közötti egyenlőségre, kormányzásra, biodiverzitásra, megújuló vízkészletekre, fogyasztásra, energiafelhasználásra, energiamegtakarításra, üvegházhatású gázok kibocsátására és megújulóenergiahasználatra vonatkozó változók értékeit lineáris függvénnyel, a többi változóértéket pedig exponenciális vagy logisztikus függvénnyel számolják ki [SSF, 2016]. A három jóléti index értéke a hozzájuk tartozó pillérváltozók értékeinek súlyozatlan mértani átlaga.

\footnotetext{
${ }^{2}$ A három jóléti mutató mögöttes mondanivalója - mint azt a szervezet honlapján kifejtik - az, hogy az ember által érzékelhető jóléti dimenziókat a fenntarthatóság Brundtland-féle meghatározásának fogalmi keretei között fejezzék ki. Lásd: http://www.ssfindex.com/ssi/ssi-2016/
} 
1. táblázat: Az emberi jólét, a környezeti jólét és a gazdasági jólét mutatóinak összetétele

\begin{tabular}{|c|c|c|}
\hline Jóléti indexek & Pillérek & Változók \\
\hline \multirow{9}{*}{ Emberi jólét } & \multirow{3}{*}{ Alapvető szükségletek } & Elegendő élelmiszer \\
\hline & & Elegendő ivóvíz \\
\hline & & $\begin{array}{l}\text { Megfelelö higiéniai } \\
\text { körülmények }\end{array}$ \\
\hline & \multirow{3}{*}{$\begin{array}{l}\text { Személyes fejlődés és } \\
\text { egészség }\end{array}$} & Oktatás \\
\hline & & Egészséges életmód \\
\hline & & Nemek közötti egyenlöség \\
\hline & \multirow{3}{*}{$\begin{array}{l}\text { Társadalmi } \\
\text { kiegyensúlyozottság }\end{array}$} & Jövedelemeloszlás \\
\hline & & Népességnövekedés \\
\hline & & Jó kormányzás \\
\hline \multirow{7}{*}{ Környezeti jólét } & \multirow{3}{*}{ Természeti erőforrások } & Biodiverzitás \\
\hline & & Megújuló ivóvízkészletek \\
\hline & & Fogyasztás \\
\hline & \multirow{4}{*}{ Klíma és energia } & Energiafelhasználás \\
\hline & & Energiamegtakarítás \\
\hline & & Üvegházhatású gázok \\
\hline & & Megújuló energia \\
\hline \multirow{5}{*}{ Gazdasági jólét } & \multirow{2}{*}{ Átmenet } & Biogazdálkodás \\
\hline & & Valódi megtakarítás \\
\hline & \multirow{3}{*}{ Gazdaság } & Bruttó nemzeti össztermék \\
\hline & & Foglalkoztatottság \\
\hline & & Államadósság \\
\hline
\end{tabular}

Forrás: Sustainable Society Foundation honlapja ${ }^{3}$ alapján saját szerkesztés

A fentebb említett NEF adatállományából származnak a boldog bolygó mutató (HPI - Happy Planet Index) nevü jólléti index értékei, amelyek egy 1-től 100-ig terjedő skálán szerepelnek. A HPI kiszámításának módja hozzávetőlegesen a következő [NEF, 2016]:

(várható élettartam x szubjektiv jóllét) x élethossz és jóllét eloszlásának egyenlötlensége / ökológiai lábnyom

Az alább bemutatásra kerülő elemzés célja elsősorban az, hogy a vizsgált adatok alapján választ adjon arra a kérdésre, hogy az egyes mutatók között van-e kapcsolat, és ha van, akkor milyen összefüggésben állnak egymással, vagyis milyen regressziófüggvény illeszthető leginkább a kapcsolatra. Magyarázóváltozóként az egy före vetített GDP-t használtam, illetve egy esetben - a környezeti jóléti mutatóval történő összevetéshez - a HPI-t is. A regressziószámítás eredményei indokolttá tették, hogy ezek ismertetését követően néhány ország esetében idősoros adatok mentén is megvizsgáljam az egy före jutó GDP, valamint az emberi jóléti, a környezeti jóléti és a gazdasági jóléti mutatók közötti kapcsolatot. Idősoros adatok az utóbbi három mutató esetében 2006 és 2016 között találhatók minden második (páros számú) évre.

\footnotetext{
${ }^{3}$ http://www.ssfindex.com/ssi/framework/
} 


\section{Eredmények}

Az egy före eső GDP és a három jóléti mutató közötti regresszióelemzés eredményeit a teljes sokaság körében a 2. táblázat foglalja össze. Mindhárom mutató esetében látható, hogy van sztochasztikus kapcsolat a magyarázó- és a függőváltozó között, a leginkább azonban egyes nemlineáris függvények írják le a kapcsolatot. Az emberi jóléti és a gazdasági jóléti mutatóknál a kapcsolat jellege hasonló nemlinearitásában, utóbbinál ugyanakkor ez jóval gyengébb. A környezeti jóléti mutató és a fejenkénti GDP között szintén egy nem túl erős, de létező kapcsolat van, ugyanakkor a viszony fordított, vagyis a nevezzük így - gazdagabb országokban általában alacsonyabb a környezeti jólét, mint a GDP/fő alapján szegényebbekben.

2. táblázat: A GDP/fő és a három jóléti mutató kapcsolata a teljes mintában

\begin{tabular}{|l|c|c|c|c|c|c|c|c|c|c|c|c|}
\hline \multirow{2}{*}{ Függvény } & \multicolumn{4}{|c|}{ Emberi jólét } & \multicolumn{4}{c|}{ Környezeti jólét } & \multicolumn{3}{c|}{ Gazdasági jólét } \\
\cline { 2 - 13 } & $\mathrm{R}^{2}$ & Szign. & Konst & $\mathrm{b} 1$ & $\mathrm{R}^{2}$ & Szign. & Konst & $\mathrm{b} 1$ & $\mathrm{R}^{2}$ & Szign. & Konst & $\mathrm{b} 1$ \\
\hline \begin{tabular}{l} 
lineáris \\
\hline $\begin{array}{l}\text { logarit- } \\
\text { mikus }\end{array}$
\end{tabular} & 0,35 & $<0,01$ & 5,61 & 0,04 & 0,47 & $<0,01$ & 6,12 & $-0,05$ & 0,31 & $<0,01$ & 3,62 & 0,04 \\
\hline inverz & 0,48 & $<0,01$ & 4,08 & 1,00 & 0,63 & $<0,01$ & 7,57 & $-1,06$ & 0,41 & $<0,01$ & 2,53 & 0,80 \\
\hline vegyes & 0,33 & $<0,01$ & 5,47 & 1,01 & 0,51 & $<0,01$ & 6,09 & 0,99 & 0,28 & $<0,01$ & 3,47 & 1,01 \\
\hline $\begin{array}{l}\text { hatvány- } \\
\text { kitevős }\end{array}$ & 0,67 & $<0,01$ & 4,28 & 0,17 & 0,57 & $<0,01$ & 8,07 & $-0,22$ & 0,41 & $<0,01$ & 2,65 & 0,19 \\
\hline $\begin{array}{l}\text { telítődé- } \\
\text { si (S) }\end{array}$ & 0,53 & $<0,01$ & 1,97 & $-0,66$ & 0,34 & $<0,01$ & 1,41 & 0,77 & 0,31 & $<0,01$ & 1,57 & $-0,74$ \\
\hline ,growth” & 0,33 & $<0,01$ & 1,70 & 0,01 & 0,51 & $<0,01$ & 1,80 & $-0,01$ & 0,28 & $<0,01$ & 1,24 & 0,01 \\
\hline $\begin{array}{l}\text { exponen- } \\
\text { ciális }\end{array}$ & 0,33 & $<0,01$ & 5,47 & 0,01 & 0,51 & $<0,01$ & 6,09 & $-0,01$ & 0,28 & $<0,01$ & 3,47 & 0,01 \\
\hline $\begin{array}{l}\text { logiszti- } \\
\text { kus }\end{array}$ & 0,33 & $<0,01$ & 0,18 & 0,99 & 0,51 & $<0,01$ & 0,16 & 1,01 & 0,28 & $<0,01$ & 0,29 & 0,99 \\
\hline
\end{tabular}

Forrás: a Világbank és a Sustainable Society Foundation adatállományai alapján saját szerkesztés

$\mathrm{Az}$ 1. ábra pontfelhőin pedig jól látszik még az is, hogy mindhárom jóléti mutatónál az alacsonyabb egy főre eső GDP-vel rendelkező országok körében erősebb a kapcsolat, mint a gazdagabbakéban. 
1. ábra: A GDP/fö és a három jóléti mutató kapcsolata a teljes mintában
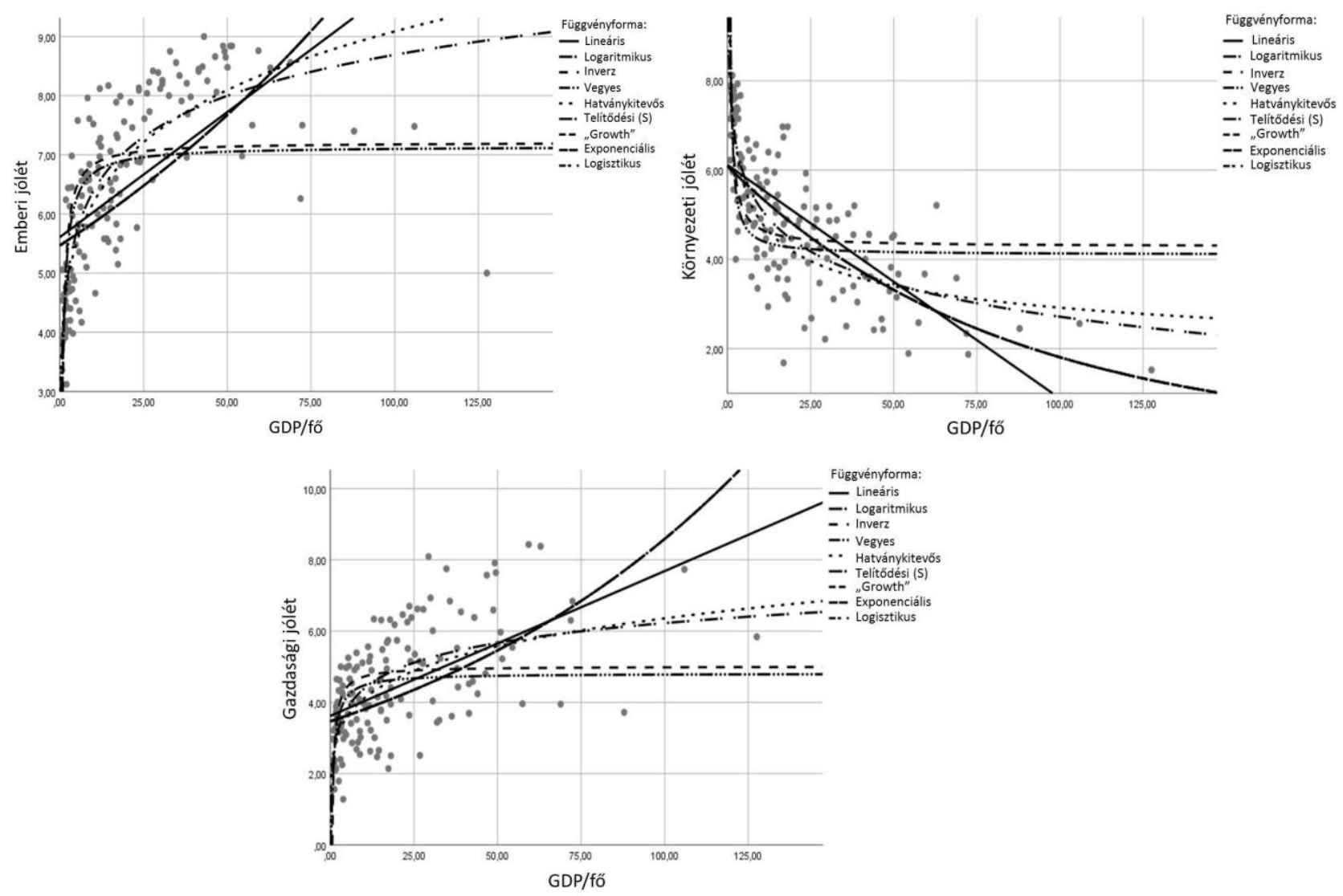

Forrás: a Világbank és a Sustainable Society Foundation adatállományai alapján saját szerkesztés

Érdemes ezért két klaszteren külön-külön is lefuttatni az elemzést, aminek eredményeit a 3. és a 4. táblázat mutatja. Az első klaszterbe a 25 amerikai dollárnál kevesebb egy före eső GDP értékkel rendelkező országokat (összesen 107 ország), a másodikba pedig a 25 vagy annál több GDP/fö értékkel rendelkezőket (összesen 43 ország) soroltam. A szegényebb országok csoportjában (3. táblázat) mindhárom jóléti mutatónál van valamilyen kapcsolat a fejenkénti GDP-vel, bár nem túl erős. Emellett az összes ország sokaságához képest némileg megváltozik a kapcsolat jellege, valamivel jobban közelít az a lineárishoz, bár egyik mutató esetében sem a lineáris becslőfüggvénynek a legjobb az illeszkedése. A gazdagabb országok csoportjában (4. táblázat) sok esetben megszünik a sztochasztikus kapcsolat. Az emberi jóléti mutató esetében a szignifikanciaszint értéke alapján vannak olyan modellek, amelyeket el kell vetnünk, a többi modellnél pedig az $\mathrm{R}^{2}$ alacsony értéke miatt kérdőjelezhető meg a kapcsolat létezése. Mindazonáltal utóbbiaknál a becsült paraméterérték (együttható) negatív értéke alapján, amennyiben elfogadjuk ezen modellek meglétét, a magasabb egy főre eső GDP-ből - a teljes sokaságtól eltérően - már inkább alacsonyabb emberijólét-értékre következtethetünk. A gazdasági jóléti mutató és az egy főre eső GDP között a gazdagabb országok körében semmilyen kapcsolat sincs, míg a környezeti jóléti mutató esetében gyenge - a teljes sokaságnál és az első klaszternél jóval gyengébb - a kapcsolat a fejenkénti GDP-vel. 
3. táblázat: A GDP/fő és a három jóléti mutató kapcsolata a szegényebb országok körében

\begin{tabular}{|c|c|c|c|c|c|c|c|c|c|c|c|c|}
\hline \multirow[b]{2}{*}{ Függvény } & \multicolumn{4}{|c|}{ Emberi jólét } & \multicolumn{4}{|c|}{ Környezeti jólét } & \multicolumn{4}{|c|}{ Gazdasági jólét } \\
\hline & $\mathrm{R}^{2}$ & $\begin{array}{c}\text { Szign } \\
.\end{array}$ & $\begin{array}{c}\text { Kons } \\
\text { t. }\end{array}$ & b1 & $\mathrm{R}^{2}$ & $\begin{array}{c}\text { Szign } \\
.\end{array}$ & $\begin{array}{c}\text { Kons } \\
\text { t. }\end{array}$ & b1 & $\mathrm{R}^{2}$ & $\begin{array}{c}\text { Szign } \\
.\end{array}$ & $\begin{array}{c}\text { Kons } \\
\text { t. }\end{array}$ & b1 \\
\hline lineáris & 0,48 & $<0,01$ & 4,67 & 0,13 & 0,40 & $<0,01$ & 6,87 & $-0,13$ & 0,32 & $<0,01$ & 3,02 & 0,10 \\
\hline $\begin{array}{l}\text { logarit- } \\
\text { mikus }\end{array}$ & 0,56 & $<0,01$ & 4,08 & 0,97 & 0,50 & $<0,01$ & 7,54 & $-1,04$ & 0,32 & $<0,01$ & 2,65 & 0,71 \\
\hline inverz & 0,44 & $<0,01$ & 6,58 & $-2,82$ & 0,40 & $<0,01$ & 4,84 & 3,06 & 0,25 & $<0,01$ & 4,49 & $-2,08$ \\
\hline vegyes & 0,48 & $<0,01$ & 4,63 & 1,02 & 0,37 & $<0,01$ & 6,85 & 0,98 & 0,27 & $<0,01$ & 2,95 & 1,03 \\
\hline $\begin{array}{l}\text { hatvány- } \\
\text { kitevős }\end{array}$ & 0,58 & $<0,01$ & 4,14 & 0,18 & 0,43 & $<0,01$ & 7,69 & $-0,19$ & 0,30 & $<0,01$ & 2,65 & 0,19 \\
\hline $\begin{array}{l}\text { telítődé- } \\
\text { si (S) }\end{array}$ & 0,48 & $<0,01$ & 1,88 & $-0,52$ & 0,33 & $<0,01$ & 1,55 & 0,54 & 0,26 & $<0,01$ & 1,47 & $-0,57$ \\
\hline ,growth" & 0,48 & $<0,01$ & 1,53 & 0,02 & 0,37 & $<0,01$ & 1,92 & $-0,03$ & 0,27 & $<0,01$ & 1,08 & 0,03 \\
\hline $\begin{array}{l}\text { exponen- } \\
\text { ciális }\end{array}$ & 0,48 & $<0,01$ & 4,63 & 0,02 & 0,37 & $<0,01$ & 6,85 & $-0,03$ & 0,27 & $<0,01$ & 2,95 & 0,03 \\
\hline $\begin{array}{l}\text { logiszti- } \\
\text { kus }\end{array}$ & 0,48 & $<0,01$ & 0,22 & 0,98 & 0,37 & $<0,01$ & 0,15 & 1,03 & 0,27 & $<0,01$ & 0,34 & 0,98 \\
\hline
\end{tabular}

Forrás: a Világbank és a Sustainable Society Foundation adatállományai alapján saját szerkesztés

4. táblázat: A GDP/fö és a három jóléti mutató kapcsolata a gazdagabb országok körében

\begin{tabular}{|l|c|c|c|c|c|c|c|c|c|c|c|c|c|}
\hline \multirow{2}{*}{ Függvény } & \multicolumn{4}{|c|}{ Emberi jólét } & \multicolumn{4}{c|}{ Környezeti jólét } & \multicolumn{4}{c|}{ Gazdasági jólét } \\
\cline { 2 - 13 } & $\mathrm{R}^{2}$ & $\begin{array}{c}\text { Szign } \\
\cdot\end{array}$ & $\begin{array}{c}\text { Kons } \\
\mathrm{t} .\end{array}$ & $\mathrm{b} 1$ & $\mathrm{R}^{2}$ & $\begin{array}{c}\text { Szign } \\
.\end{array}$ & $\begin{array}{c}\text { Kons } \\
\mathrm{t}\end{array}$ & $\mathrm{b} 1$ & $\mathrm{R}^{2}$ & $\begin{array}{c}\text { Szign } \\
.\end{array}$ & $\begin{array}{c}\text { Kons } \\
\mathrm{t}\end{array}$ & $\mathrm{b} 1$ \\
\hline lineáris & 0,20 & $<0,01$ & 8,80 & $-0,02$ & 0,26 & $<0,01$ & 4,78 & $-0,02$ & 0,03 & 0,28 & 5,09 & 0,01 \\
\hline $\begin{array}{l}\text { logarit- } \\
\text { mikus }\end{array}$ & 0,10 & 0,04 & 10,46 & $-0,65$ & 0,26 & $<0,01$ & 8,91 & $-1,41$ & 0,04 & 0,23 & 2,83 & 0,76 \\
\hline inverz & 0,03 & 0,26 & 7,59 & 17,12 & 0,22 & $<0,01$ & 2,11 & 60,41 & 0,04 & 0,23 & 4,53 & $-34,97$ \\
\hline vegyes & 0,23 & $<0,01$ & 9,00 & 1,00 & 0,32 & $<0,01$ & 5,11 & 0,99 & 0,03 & 0,28 & 4,90 & 1,00 \\
\hline $\begin{array}{l}\text { hatvány- } \\
\text { kitevős }\end{array}$ & 0,12 & 0,02 & 11,61 & $-0,1$ & 0,29 & $<0,01$ & 18,94 & $-0,45$ & 0,04 & 0,23 & 3,19 & 0,14 \\
\hline $\begin{array}{l}\text { telítődési } \\
\text { (S) }\end{array}$ & 0,04 & 0,18 & 2,01 & 2,80 & 0,24 & $<0,01$ & 0,77 & 18,90 & 0,04 & 0,22 & 1,86 & $-6,69$ \\
\hline „growth” & 0,23 & $<0,01$ & 2,20 & 0,00 & 0,32 & $<0,01$ & 0,16 & $-0,01$ & 0,03 & 0,28 & 1,59 & 0,00 \\
\hline $\begin{array}{l}\text { exponen- } \\
\text { ciális }\end{array}$ & 0,23 & $<0,01$ & 9,00 & 0,00 & 0,32 & $<0,01$ & 5,10 & $-0,01$ & 0,03 & 0,28 & 4,90 & 0,00 \\
\hline $\begin{array}{l}\text { logiszti- } \\
\text { kus }\end{array}$ & 0,23 & $<0,01$ & 0,11 & 1,00 & 0,32 & $<0,01$ & 0,20 & 1,01 & 0,03 & 0,28 & 0,20 & 1,00 \\
\hline
\end{tabular}


A boldog bolygó mutató (HPI) esetében a teljes sokaságra futtatott regresszióelemzés olyan alacsony $\mathrm{R}^{2}$ értékeket mutat, hogy nem nagyon lehet közte és az egy före jutó GDP mutatója között fennálló kapcsolatról beszélni (5. táblázat). A 2. ábrán is látható, hogy egyetlen trendvonal sem illeszthető igazán a pontfelhőre, legfeljebb csak a legszegényebb országok között hat a GDP/fő értéke valamelyest a boldog bolygó mutatóra.

5. táblázat: A GDP/fö és a boldog bolygó mutató kapcsolata a teljes mintában

\begin{tabular}{|l|c|c|c|c|}
\hline Függvény & $\mathrm{R}^{2}$ & Szignifikancia & Konstans & $\mathrm{b} 1$ \\
\hline lineáris & 0,02 & 0,12 & 25,63 & 0,06 \\
\hline logaritmikus & 0,10 & $<0,01$ & 21,92 & 1,95 \\
\hline inverz & 0,15 & $<0,01$ & 28,70 & $-11,45$ \\
\hline vegyes & 0,02 & 0,10 & 24,51 & 1,00 \\
\hline hatványkitevős & 0,11 & $<0,01$ & 20,91 & 0,08 \\
\hline telítődési (S) & 0,16 & $<0,01$ & 3,33 & $-0,48$ \\
\hline „growth” & 0,02 & 0,10 & 3,12 & 0,00 \\
\hline exponenciális & 0,02 & 0,10 & 24,51 & 0,00 \\
\hline logisztikus & 0,02 & 0,10 & 0,04 & 0,99 \\
\hline
\end{tabular}

Forrás: a Világbank és a New Economics Foundation adatállományai alapján saját szerkesztés

2. ábra: A GDP/fö és a boldog bolygó mutató kapcsolata a teljes mintában

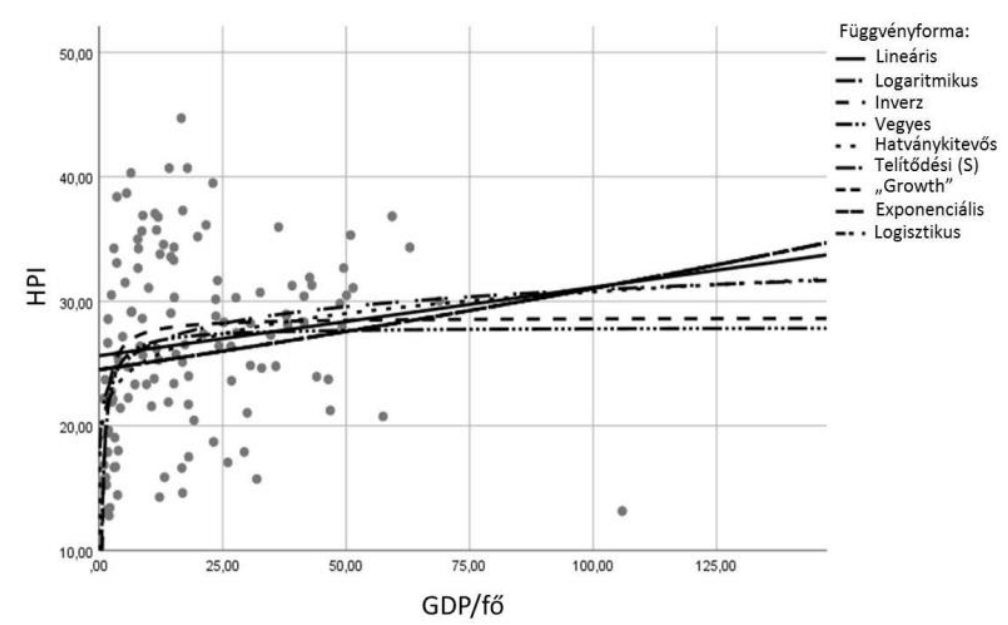

Forrás: a Világbank és a New Economics Foundation adatállományai alapján saját szerkesztés

A vizsgált alternatív mérőszámok közül tehát a HPI mutat a legkevésbé bármiféle összefüggést az átlagos fejenkénti GDP értékével, a többi mutató esetében az összes ország sokaságát vizsgálva létezik valamilyen erősebb vagy gyengébb sztochasztikus kapcsolat. Ezek közül a környezeti jóléti mutató egy gyenge negatív összefüggést mutat az egy főre eső GDP-vel, vagyis az utóbbi magasabb értékéből általánosságban inkább az előbbi alacsonyabb értékére következtethetünk. Ezek alapján érdemes lehet még megnézni azt is, hogy a környezeti jólét és a HPI országmutatók között létezik-e valamilyen kapcsolat. A 6. táblázatban látható eredmények alapján nem beszélhetünk ilyenről az összes ország viszonylatában, ugyanakkor a 3. ábra pontfelhőjén a legmagasabb HPI-vel bíró országoknál láthatunk némi összefüggést ezen értékek és a környezeti jólétet mutató értékek között. Ez indokolttá teszi, hogy csak a legmagasabb 
HPI értékkel rendelkező 12 ország körében külön is elvégezzük a korrelációanalízist. (A NEF adatállománya alapján ezek az országok kaptak ,jó” besorolást, míg a többi ország „,közepes” vagy „gyenge” besorolású.) A 7. táblázatban az látható, hogy ebben a klaszterben megjelenik egy nem túl erős, leginkább lineáris jellegü kapcsolat. Mivel a magyarázóváltozó (HPI) egy részben szubjektív, részben pedig objektív jólléti mutató, míg az eredményváltozó (környezeti jólét) pillérértékei többnyire objektíven mérhetők, azt mondhatnánk mindezek alapján, hogy a legmagasabb HPI értéket kapó országok körében hangsúlyosabban jelennek meg az objektív szempontok (várható élettartam, ökológiai lábnyom), míg a többi országnál inkább a szubjektív jólét a meghatározó. Ugyanakkor megjegyzendő, hogy ez a 12 elemü részsokaság önmagában még nem elég ahhoz, hogy a kapcsolatnak egyértelmü érdemi tartalmat tulajdonítsunk. Amennyiben a jövőben más éves adatokkal vizsgált elemzés is hasonló eredményt mutat, az némiképp megerősítheti a fenti következtetést.

6. táblázat: A boldog bolygó mutató és a környezeti jólét mutatójának kapcsolata a teljes mintában

\begin{tabular}{|l|c|c|c|c|}
\hline Függvény & $\mathrm{R}^{2}$ & Szignifikancia & Konstans & $\mathrm{b} 1$ \\
\hline lineáris & 0,01 & 0,18 & 5,78 & $-0,03$ \\
\hline logaritmikus & 0,02 & 0,10 & 7,68 & $-0,80$ \\
\hline inverz & 0,03 & 0,06 & 4,26 & 20,41 \\
\hline vegyes & 0,00 & 0,84 & 4,94 & 1,00 \\
\hline hatványkitevős & 0,00 & 0,65 & 5,63 & $-0,05$ \\
\hline telítődési (S) & 0,00 & 0,51 & 1,51 & 1,53 \\
\hline „growth” & 0,00 & 0,84 & 1,60 & 0,00 \\
\hline exponenciális & 0,00 & 0,84 & 4,94 & 0,00 \\
\hline logisztikus & 0,00 & 0,84 & 0,20 & 1,00 \\
\hline
\end{tabular}

Forrás: a New Economics Foundation és Sustainable Society Foundation adatállományai alapján saját szerkesztés

3. ábra: A boldog bolygó mutató és a környezeti jólét mutatójának kapcsolata a teljes mintában

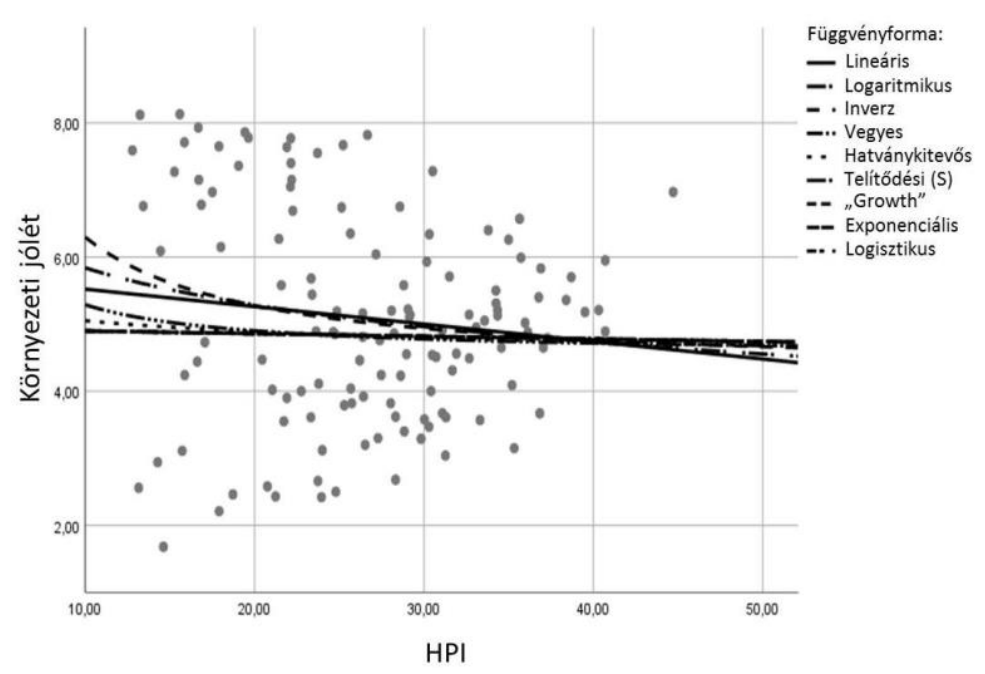

Forrás: a New Economics Foundation és Sustainable Society Foundation adatállományai alapján saját szerkesztés 
7. táblázat: A boldog bolygó mutató és a környezeti jólét mutatójának kapcsolata a legmagasabb HPI-értékkel rendelkező 12 országban

\begin{tabular}{|l|c|c|c|c|}
\hline Függvény & $\mathrm{R}^{2}$ & Szignifikancia & Konstans & $\mathrm{b} 1$ \\
\hline lineáris & 0,44 & 0,02 & $-3,51$ & 0,23 \\
\hline logaritmikus & 0,43 & 0,02 & $-27,57$ & 8,98 \\
\hline inverz & 0,42 & 0,02 & 14,43 & $-354,87$ \\
\hline vegyes & 0,39 & 0,03 & 1,05 & 1,04 \\
\hline hatványkitevős & 0,38 & 0,03 & 0,01 & 1,64 \\
\hline telítődési (S) & 0,37 & 0,03 & 3,33 & $-65,17$ \\
\hline „growth” & 0,39 & 0,03 & 0,05 & 0,04 \\
\hline exponenciális & 0,39 & 0,03 & 1,05 & 0,04 \\
\hline logisztikus & 0,39 & 0,03 & 0,95 & 0,96 \\
\hline
\end{tabular}

Forrás: a New Economics Foundation és Sustainable Society Foundation adatállományai alapján saját szerkesztés

A fentieken túl még többféleképpen is össze lehet vetni az egyes mutatókat az összes ország és/vagy egy-egy országcsoport viszonylatában, és bizonyára találnánk az eredmények között további érdekes összefüggéseket. A tanulmány terjedelme és adatkorlátok miatt végül csak az emberi, környezeti és gazdasági jóléti mutatók, illetve az egy főre eső GDP időbeli alakulását vizsgálja meg néhány konkrét ország esetében 2006 és 2016 között. A diagramon történő könnyebb ábrázolás és jobb összevethetőség érdekében a három jóléti mutató értékeit 10-zel felszoroztam, így azok 10-es helyett 100-as skálán jelennek meg. Az egy före vetített GDP mértékegysége változatlanul az amerikai dollár vásárlóerő-paritáson számolva. A 4. ábra a négy visegrádi ország, Csehország, Lengyelország, Magyarország és Szlovákia értékeinek alakulását veti össze.

4. ábra: Az egy főre eső GDP és a három jóléti mutató alakulása a négy visegrádi országban 2006 és 2016 között
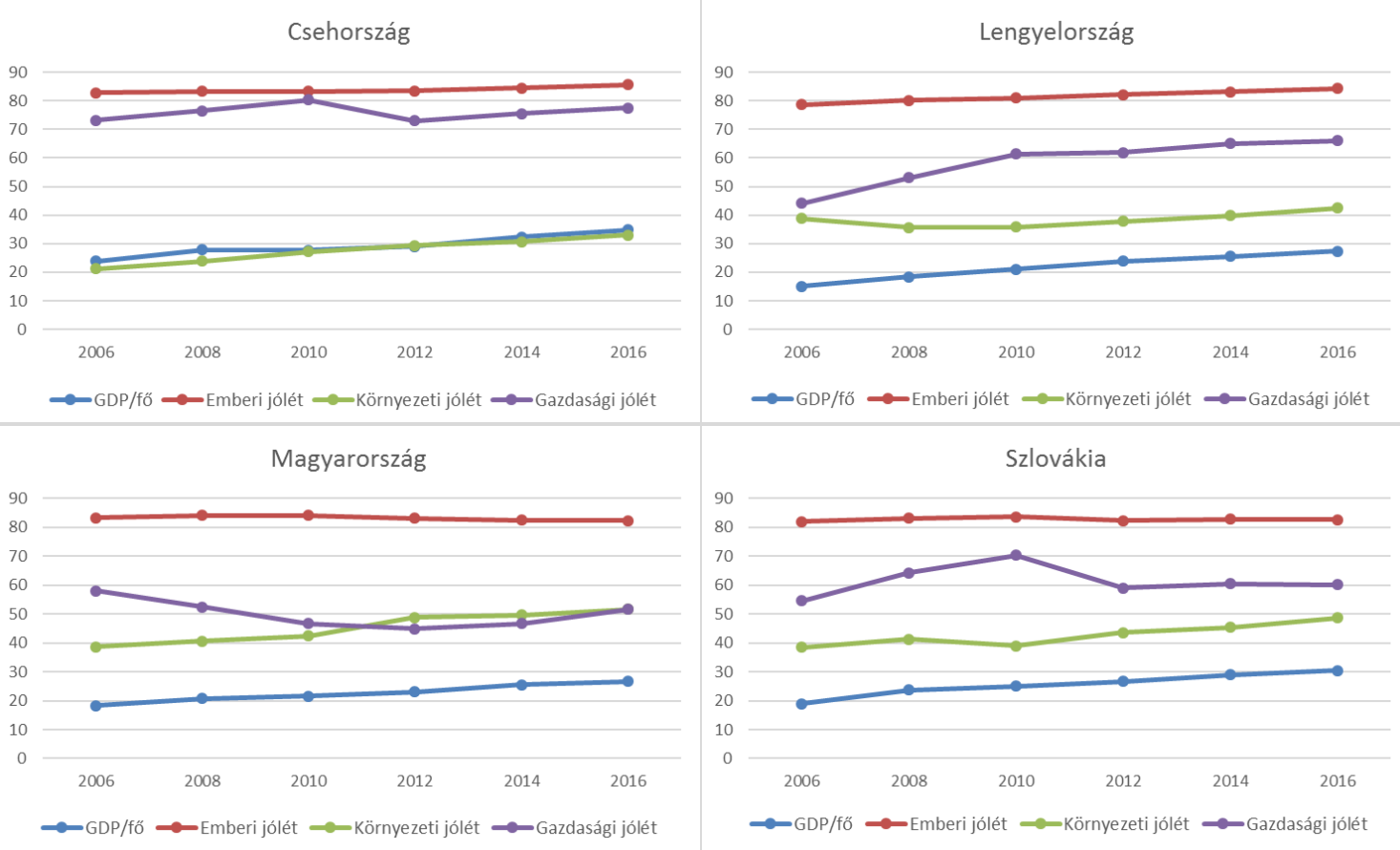

Forrás: saját szerkesztés 
Az egy főre eső GDP mind a négy országnál egy nagyjából egyenletes lassú növekedést mutat a vizsgált tíz év alatt. (Ez a növekedés Magyarország esetében volt a leglassabb.) Az emberi jólét értékei szinte stagnálnak, legfeljebb Lengyelországnál látható némi növekvő tendencia. Bár eltérő trendvonalak mentén, de a környezeti jóléti mutató összességében növekedett 2006 és 2016 között mindegyik vizsgált országban. A leginkább különböző tendenciák a gazdasági jólét mutatójának alakulásában figyelhetők meg. Ez azért érdekes, mert ennek a kompozit mutatónak az egyik változója éppen a bruttó nemzeti össztermék, vagyis a GDP. A magyarázat bizonyosan a többi változóérték alakulásában keresendő. Ha visszanézünk az 1. ábrára, látjuk, hogy a gazdasági jólét változói a bruttó nemzeti össztermék mellett a foglalkoztatottság, az államadósság, a (társadalmi és környezeti szempontokat is figyelembe vevő) valódi megtakarítási ráta, illetve a biogazdálkodás. Utóbbi kettő az úgynevezett átmeneti gazdaság pilléréhez tartozik, míg a többi három a hagyományos gazdasági szerkezet pillérét képezi. Mindezek tükrében érdemes összevetni külön csak a gazdasági jólét mutatóját alkotó változóknak az alakulását is, amit az 5. ábra mutat. A GDP értékei itt - a többi változóértékkel együtt - 10-es skálára aggregált adatként jelennek meg. ${ }^{4}$ A gazdasági jólét egyes változóinak idősoros grafikus összevetéséből jól látható, hogy a GDP-től többnyire valóban eltérően alakult a többi változó értéke mind a négy visegrádi országban. Az is látható még, hogy ezen további változóknak mind az egymáshoz képesti, mind az országok közötti alakulása eltérő tendenciákat mutat; a visegrádi országok közötti összehasonlításban csak a GDP értéke változott hasonlóképpen 2006 és 2016 között.

5. ábra: A gazdasági jóléti mutató változóinak alakulása a négy visegrádi országban 2006 és 2016 között

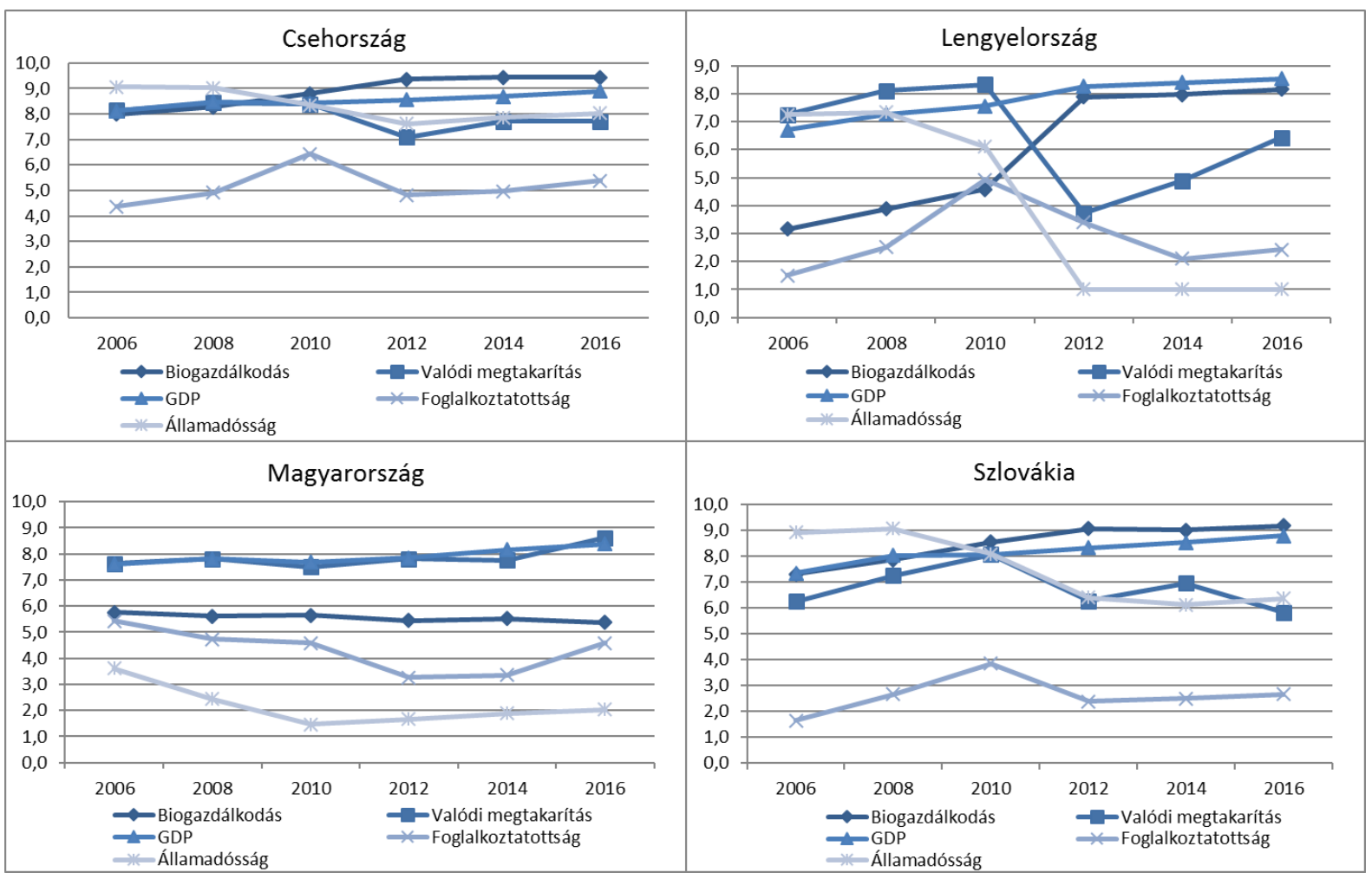

Forrás: saját szerkesztés

\footnotetext{
${ }^{4}$ Az 5. ábrán látható GDP értékek - a tanulmányban bemutatott többi elemzéstől eltérően - nem a vásárlóerő-paritáson mért egy före eső GDP-t, hanem az abból az SSI által használt exponenciális függvénnyel kiszámolt aggregált értékeket mutatják [SSF, 2016].
} 
Végezetül négy további, globális viszonylatban is jelentős ország esetében kerül összevetésre a fejenkénti GDP az említett három jóléti mutatóval, nevezetesen az Egyesült Államok, Kína, Németország és Oroszország vonatkozásában (6. ábra). Ennél a négy országnál talán kevésbé mutat eltérö tendenciát az egyes mutatók változása, mint a visegrádi országok esetében, de néhány érdekesség itt is megfigyelhető. Az Egyesült Államok vonaldiagramján látható például, hogy - a visegrádi országcsoporthoz hasonlóan - a gazdasági jólét tér el leginkább a GDP trendjétől, míg a legdinamikusabb GDP növekedést produkáló Kínában egyedüliként csökkent jelentősen a környezeti jólét értéke, igaz, 2016-ban már némi javulás látható 2014-hez képest. Ugyanakkor a környezeti jólét egyik országnál sem követi a GDP értékének növekvő tendenciáját, cáfolva azt a vélekedést, miszerint a GDP-ben megjelenő nagyobb növekedési ütemmel lehetne megalapozni egy jobb környezetpolitikát.

6. ábra: Az egy főre eső GDP és a három jóléti mutató alakulása az Egyesült Államokban, Kínában, Németországban és Oroszországban 2006 és 2016 között
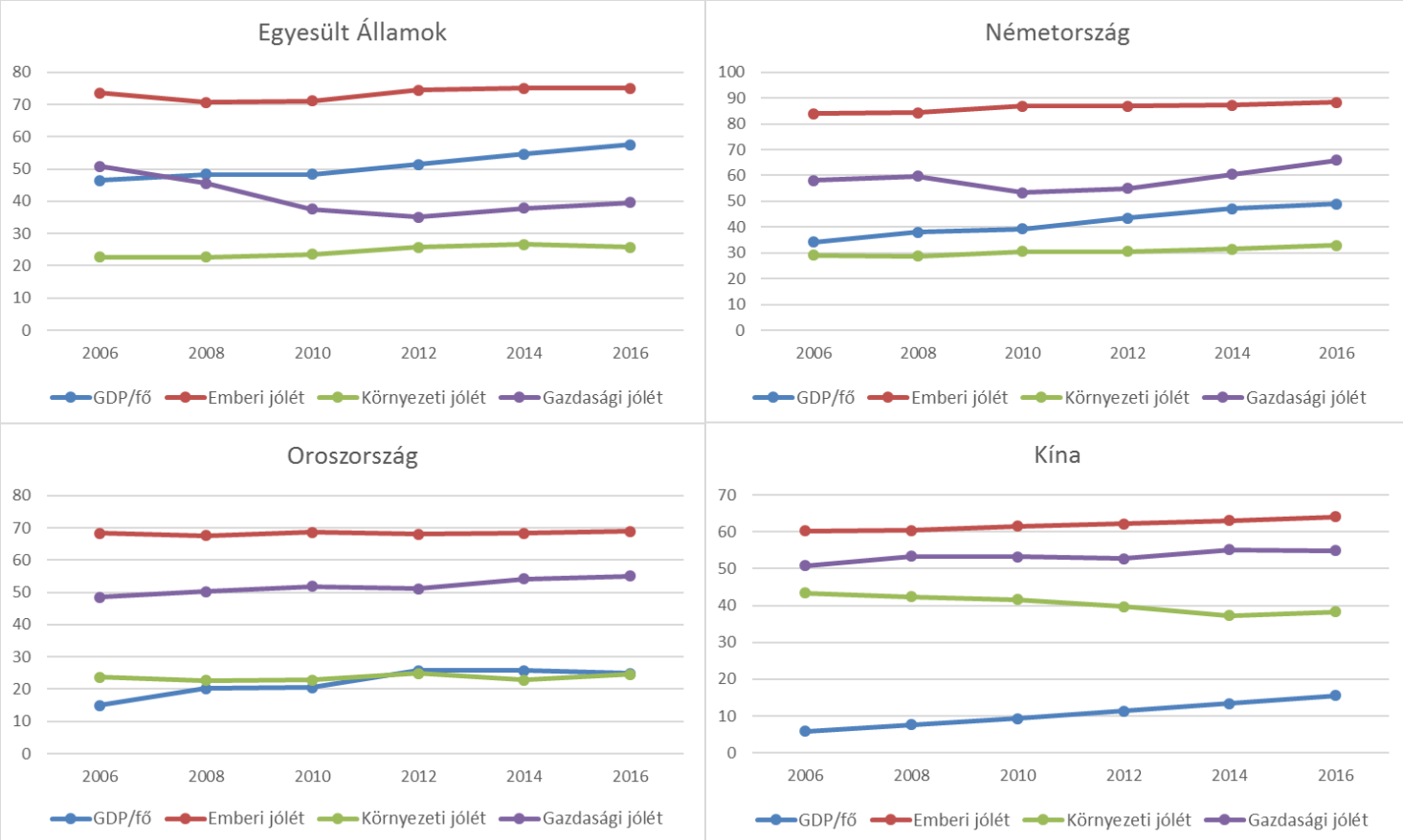

Forrás: saját szerkesztés

Az adatelemzés eredményeinek iménti, nem teljes körü kiértékelésének az volt a célja, hogy rámutasson, mennyire nem egyértelmü a fejlődés és fejlettség fogalmának értelmezése. A tanulmány a kiértékelés összegzésével és néhány általános következtetés levonásával zárul.

\section{4. Összegzés és következtetések}

A dolgozat célja nem az volt, hogy valamilyen új megállapítást fogalmazzon meg, hanem az, hogy egy már meglévőt támasszon alá (vagy esetleg cáfoljon meg) számadatok alapján. Ez a megállapítás konkrétan az, hogy az aggregált termelékenységi és fogyasztási mutatók - amelyek közül a legáltalánosabban használt a GDP - nem alkalmasak arra, hogy a fejlettség és fejlődés egyedüli kifejezői legyenek. Jóllehet a fejlődés fogalma semelyik mutatóval sem ragadható meg és fejezhető ki egyedüliként annak összetettsége miatt [Grasso-Canova, 2007]. A gondolat tágabb elméleti hátterében az úgynevezett ökológiai gazdaságtan megközelítése áll, miszerint a gazdálkodás teljes rendszerét, vagyis a tágabb társadalmi és (a még tágabb) ökológiai környezet állapotváltozóit is figyelembe kell venni, és annak a fejlesztéspolitikának kellene 
érvényesülnie, amelyik ezek közül az aktuálisan rosszabb állapotban lévőnek a javítását tüzi ki célul [Zsolnai, 2001].

A fenti tételt elfogadva természetesen még továbbra is kérdés marad az, hogy milyen változókkal lehet leginkább mérni a gazdaság, a társadalom és a környezet állapotát. Ehhez lehet különféle objektív és szubjektív, materiális és immateriális változókat használni proxy változókként, de célszerü minden esetben több változóból álló kompozit indexeket is bevonni a vizsgálatba. A tanulmány négy ilyen indexet - az emberi jóléti mutatót, a környezeti jóléti mutatót, a gazdasági jóléti mutatót és a boldog bolygó mutatót vetett össze az egy főre eső GDP-vel 150 ország teljes sokaságában és esetenként azok részsokaságaiban, illetve néhány ország esetében egyes mutatók idősorosan is összehasonlításra kerültek. Az elemzés eredményei alapján az alábbi következtetések fogalmazhatók meg.

1. Az emberi jóléti mutató (HW) és a gazdasági jóléti mutató (EcW) esetében leginkább logisztikus jellegü gyenge sztochasztikus kapcsolat jellemző a fejenkénti GDP-vel való viszonyra. Ez megerősíti azt a feltevést, hogy a termelékenységnek és fogyasztásnak egy bizonyos szint utáni további növekedése egyre kevésbé eredményez jóléti fejlődést.

2. A környezeti jóléti mutató (EnW) és az egy főre eső GDP közötti sztochasztikus viszony negatív előjelü logaritmikus kapcsolatként határozható meg leginkább. A nemlineáris kapcsolat ebben az esetben arra utal, hogy a gazdagabb országokban jobban megengedhetik a környezetbarát gyártási technológiák alkalmazását és/vagy a szennyező tevékenységek kihelyezését a szegényebb országokba.

3. A boldog bolygó mutató (HPI) és az egy före eső GDP között nincs sztochasztikus kapcsolat, a két mutató értékei függetlenek egymástól.

4. Azoknál a mutatóknál, ahol a teljes sokaság körében van valamilyen sztochasztikus kapcsolat az egy főre eső GDP-vel, a szegényebb - vagyis alacsonyabb GDP/fö értékkel rendelkező - országok részsokaságában erősebb a kapcsolat, mint a gazdagabbakéban, illetve a gazdasági jóléti mutatónál a gazdagabb országok körében megszünik a sztochasztikus kapcsolat. Ez egybevág az 1. és 2. pontban írtakkal a kapcsolatok nemlineáris jellegéről a teljes sokaságban.

5. Az objektív változókból álló környezeti jóléti mutató és a többnyire szubjektív boldog bolygó mutató között az összes ország sokaságában nincs összefüggés, de a - 2016-os adatok alapján - 12 legmagasabb HPI-értékkel rendelkező ország esetében megjelenik egy gyenge lineáris jellegű sztochasztikus kapcsolat.

6. A 2006 és 2016 közötti időszakban külön megvizsgált négy visegrádi országnál az egy főre eső GDP egyenletes lassú növekedést mutat, az emberi és a környezeti jóléti mutatók összességében stagnálnak vagy kissé javultak, míg a gazdasági jólét mutató eltérő trendvonalak mentén alakult. Az eredmény indokolttá teszi az utóbbi mutató változóinak külön összevetését is, amely megerősíti, hogy a GDP kivételével a változók sajátosan, mind a négy vizsgált ország esetében más-más módon alakultak.

7. Az egy före eső GDP és a három jóléti mutató 2006-2016 közötti időszakra nézett idősoros összevetésére a visegrádi országokon kívül még további négy ország - Egyesült Államok, Kína, Németország és Oroszország - esetében is sor került. Ezek közül kiemelendő, hogy az Egyesült Államoknál a visegrádi országokhoz hasonlóan a gazdasági jólét tér el leginkább a GDP trendjétől, míg a legdinamikusabb GDP növekedést produkáló Kínában egyedüliként csökkent jelentősen a környezeti jólét értéke.

A vizsgált változókkal még sokféle további elemzést is el lehet végezni különböző szempontok szerint. A tanulmány célja az itt bemutatott elemzéssel elsősorban az volt, hogy számszerüleg is rámutasson arra, hogy a fejlettség és fejlödés fogalmának minél tágabb és minél többféle értelmezési lehetőségét vesszük alapul, annál kevésbé lehet azt pusztán a GDP mérőszámával megragadni. Láthattuk továbbá, hogy kimondottan csak a gazdasági fejlődés sem fejezhető ki egyedüliként ezzel a mutatóval, sőt sokszor háttérbe 
szorul ez az egyéb szempontokat tükröző és a gazdaság állapotát jobban kifejező változókhoz képest. Ebből nem következik a GDP célszerüségének és használatának elvetése - legalábbis a közeljövőben még bizonyosan szükség lesz ennek további mérésére -, azt viszont már régóta újra kellene gondolniuk a döntéshozóknak, mikor és mekkora súlyú döntéseket hoznak meg úgy, hogy többnyire csak e mutató értékének várható alakulását veszik alapul.

\section{Felhasznált irodalom és adatállományok}

Bródy A. (1983): Lassuló idő. A gazdasági bajok magyarázatához. Közgazdasági és Jogi Könyvkiadó, Budapest Európai Bizottság (2009): A GDP-n innen és túl. A haladás mérése változó világunkban. A Bizottság közleménye a Tanácsnak és az Európai Parlamentnek.

http://www.europarl.europa.eu/meetdocs/2009_2014/documents/com/com_com(2009)0433_/com_com(2009)04 33_hu.pdf. Lekérdezve: 2018.10.26.

Daly, H. E. és Cobb, J. B. (1989): For the Common Good: Redirecting the Economy. Toward Community, the Environment, and a Sustainable Future. Boston, Massachusetts: Beacon Press

Galambosné Tiszberger M. (2016): „Jól(1)ét és fejlettség mérés. Kísérlet regionális szintủ mutató készítésére”. In: Erdős Katalin és Komlósi Éva (szerk.): Tanitványaimban élek tovább. Emlékkötet Buday-Sántha Attila tiszteletére. Pécsi Tudományegyetem Közgazdaságtudományi Kar, Pécs

Grasso, M. és Canova, L. (2007): „An Assessment of the Quality of Life in the European Union based on the Social Indicators Approach" Social Indicators Research 87(1): 1-26.

Jacobs, G. és Šlaus, I. (2010): „Indicators of Economic Progress: The Power of Measurement and Human Welfare” Cadmus 1(1): 53-113.

Kerényi Á. (2011): „A Gazdasági Együttműködési és Fejlesztési Szervezet Better Life indexének bemutatása” Pénzügyi Szemle 56(4): 506-526.

Kornai J. (1972): Eröltetett vagy harmonikus növekedés. Gondolatok a gazdasági növekedés elméletéröl és politikájáról. Akadémiai Kiadó, Budapest

New Economic Foundation (2015): Five headline indicators of national success. http://b.3cdn.net/nefoundation/1ff58cfc7d3f4b3fad_04m6ynyiz.pdf. Lekérdezve: 2018.10.26.

New Economic Foundation (2016): Happy Planet Index 2016. Methods Paper. https://static1.squarespace.com/static/5735c421e321402778ee0ce9/t/578dec7837c58157b929b3d6/1468918904 805/Methods+paper 2016.pdf. Lekérdezve: 2018.10.26.

Régiók Bizottsága (2016): Területfejlesztési mutatók - a GDP-n innen és túl. Véleménytervezet https://www.borbolycsaba.ro/wp-content/uploads/2014/01/HU Ter\%C3\%BCletfejleszt\%C3\%A9simutat\%C3\%B3k-GDPn-innen-es-tul velemenytervezet.pdf. Lekérdezve: 2018.10.26.

Stiglitz, J. E., Sen, A. és Fitoussi, J-P. (szerk.) (2009): Report by the Commission on the Measurement of Economic Performance and Social Progress.

http://library.bsl.org.au/jspui/bitstream/1/1267/1/Measurement of economic performance and social_progress .pdf. Lekérdezve: 2018.10.26.

Sustainable Society Foundation (2016): Calculation formulas of the Sustainable Society Index, SSI-2016. http://www.ssfindex.com/ssi2016/wp-content/uploads/pdf/calculation-formulas-2016.pdf.

Lekérdezve: 2018.10.26.

Zsolnai L. (2001): Ökológia, gazdaság, etika. Helikon Kiadó, Budapest

Világbank adatbázisa: https://data.worldbank.org/indicator/NY.GDP.PCAP.CD

Sustainable Society Foundation (SSF) adatállománya: http://www.ssfindex.com/data-all-countries/

New Economics Foundation (NEF) adatállománya: http://happyplanetindex.org/ 